\title{
Penicillium expansum versus Antagonist Yeasts and Patulin Degradation in vitro
}

\author{
Alexandre Rodrigo Coelho ${ }^{1}$, Marcos Giovani Celli ${ }^{3}$, Elisabete Yurie Sataque Ono ${ }^{2}$, Gilvan \\ Wosiacki $^{3}$, Fernando Leite Hoffmann ${ }^{4}$, Fernando Carlos Pagnocca ${ }^{5}$ and Elisa Yoko \\ Hirooka $^{1}$ \\ ${ }^{1}$ Department of Food and Drug Technology; ${ }^{2}$ Department of Biochemistry and Biotechnology, State University of \\ Londrina, coelhoar@hotmail.com, P.O. Box 6001, 86051-980,Londrina, Parana, Brazil; ${ }^{3}$ Department of Food \\ Engineering, State University of Ponta Grossa, 84030-900, Ponta Grossa, Parana, Brazil; ${ }^{4}$ Department of Food \\ Engineering and Technology, UNESP-Sao Jose do Rio Preto, Sao Paulo, Brazil; ${ }^{5}$ UNESP-Rio Claro, Sao Paulo, \\ Brazil.
}

\begin{abstract}
Taking into account the preliminary antagonistic/biodegradation property showed by Pichia membranifaciens and Sporobolomyces roseus, which decreased the initial patulin concentration of 588.4 to $290.0 \mu \mathrm{g} / \mathrm{mL}$, ability of P. ohmeri 158 in biocontrol against Penicillium expansum and patulin decrease in vitro was performed. The culture supernatant of P. ohmeri 158 was effective against $66.17 \%$ micelial growth, indicating antibiosis related with the killer phenomenon. The initial patulin concentration of $223 \mu \mathrm{g}$ in the presence of P. ohmeri 158 cells was decreased over $83 \%$ of the original concentration, when incubated at $25^{\circ} \mathrm{C} / 2$ days and $>99 \%$ after 5 days incubation time, with undetectable patulin level after 15 days. The initial pH 4.0 decreased to $p H 3.3$ along 15 days experiment, suggesting that patulin decrease was an active process and a consequence of yeast metabolism. The results suggested that $P$. ohmeri 158 could be a promising alternative for the inhibition of $P$. expansum growth and patulin degradation.
\end{abstract}

Key words: Penicillium expansum, antagonist yeasts, biocontrol, patulin, degradation

\section{INTRODUCTION}

The perishable post-harvest fruits should be free of fungal deterioration trigged by the environmental factors as mechanical damages caused by the harvest and storage (Arras et al., 1998; Hussein and Brasel, 2001). Phytosanity can be the critical point in the food safety in the globalized agribusiness, where the Brazilian fresh fruits have been introduced as promising natural food (World Health Organization-International Agency for Research on Cancer-WHO-IARC, 1996; Food and
Drug Administration-FDA, 2002). The Food and Agricultural Organization (FAO) estimated contamination with mycotoxins in $25 \%$ of the world's crop, and the main fungi involved belonged to the Aspergillus, Penicillium and Fusarium genera (Pitt et al., 2000; Ono et al., 2006). However, the predominant post-harvest fungus in apple is patulin producing Penicillium expansum. This mycotoxin causes gastrointestinal distress and neurotoxic effect in the rodents, immunotoxicity in mice and rabbit, and genotoxicity in the mammalian cells (Hopkins,

\footnotetext{
* Author for correspondence
} 
1993; Sharma, 1993; Wouters and Speijers, 1996; Moss and Long, 2002).

The control of diseases in the post-harvest fruit is based on the chemical fungicides, but progressive loss of the effectiveness and the emergence of resistant pathogens are the topic of concern, due to the increasing level of agrotoxic residues (Sugar and Spotts, 1999; Castoria et al., 2001). Biological control using antagonist microorganism has been a promising alternative, which provides safe application in both human health and ecosystem (Janisiewicz et al., 2000; Usall et al., 2001). Emphasized is the biological control using yeast, i.e. safe antagonist without health hazard coupled with low ecological impact, reliable in refrigerated storage of fruit (Usall et al., 2001). Patulin degradation to (E)-ascladiol involved fermentative process by Saccharomyces cerevisiae (Sumbu et al., 1983; Moss and Long, 2002).

In our previous study, screening of 44 yeasts isolated from the different ecosystem source showed fifteen isolates with inhibitory activity against $P$. expansum strain \#2 based on the nutrient and space competition, and five strains with antagonism based on antibiosis, with the culture supernatant of $C$. guilliermondii $\mathrm{P} 3$ and $P$. ohmeri 158 showing the higher antagonism (Levy et al., 2002; Levy, 2003; Coelho, 2005). Levy et al (2002) demonstrated the decrease of patulin in vitro using Pichia membranifaciens and Sporobolomyces roseus strains. However, the use of antagonist yeasts with wide activity and patulin decrease could be promising, and additional studies about the mode of action would be necessary before in vivo application. Taking into account the prominent activity of $P$. ohmeri 158 against mycotoxin producing $P$. expansum in solid culture, the antifungal activity in broth culture and patulin decrease by Pichia ohmeri was evaluated in vitro in this work.

\section{MATERIALS AND METHODS}

\section{Microorganisms}

Single spored $P$. expansum strain \#2 isolated from the apple was used as test microorganism (107 $\mu \mathrm{g} / \mathrm{mL}$ patulin production). $P$. expansum was subcultured each six months on Potato Dextrose agar $\left(\mathrm{PDA}, 21^{\circ} \mathrm{C} / 120 \mathrm{~h}\right.$ ), and stored at $4^{\circ} \mathrm{C}$. The spore inoculum was prepared suspending reactivated culture into $3 \mathrm{~mL}$ sterile distilled water with $0.1 \%(\mathrm{v} / \mathrm{v})$ Tween 80 , and it was adjusted to 1 x $10^{5}$ spores $/ \mathrm{mL}$ (Newbauer chamber). $C$. guilliermondii $\mathrm{P} 3$ and $P$. ohmeri 158 were isolated from the papaya and anthill, respectivelly, and biochemically characterized by the conventional method (Kreeger Van Rij, 1984; Barnett et al., 1990) and API $20 \mathrm{C}$ AUX test (Biomérieux Vitek, Marcy-1'Etoile, France), followed by identification according to Kurtzman and Fell (1998). C. guilliermondii $\mathrm{P} 3$ and $P$. ohmeri 158 grown on the surface of GYMP agar slant (2.0\% glucose, $1.0 \%$ malt extract, $0.5 \%$ yeast extract, $0.2 \% \mathrm{NaHPO}_{4}$ and $1.8 \%$ agar) were maintained at $4^{\circ} \mathrm{C}$, carrying out each six months reactivation in the same culture medium. For assay, the strains were activated on Yeast medium (YM agar-2.0\% glucose, $0.5 \%$ yeast extract, $1.0 \% \mathrm{NaCl}, 0.23 \%$ $\mathrm{NaH}_{2} \mathrm{PO}_{4}, 0.5 \%\left(\mathrm{NH}_{4}\right)_{2} \mathrm{SO}_{4}, 1.8 \%$ agar) at $25^{\circ} \mathrm{C} / 48$ h (Levy, 2003).

\section{Antagonism in broth culture}

C. guilliermondii $\mathrm{P} 3$ and $P$. ohmeri 158 were activated in $\mathrm{YM}$ broth culture at $25^{\circ} \mathrm{C} / 24 \mathrm{~h}(150$ $\mathrm{rpm})$, and $100 \mu \mathrm{L}$ of cell suspension $\left(3.0 \times 10^{6}\right.$ cells) was inoculated in five Erlenmeyer flasks (25 $\mathrm{mL}$ of $\mathrm{YM}$ broth) and incubated at $25^{\circ} \mathrm{C}$ in static condition. Each 24, 48, 72, 96 and 120 h, one of flask was centrifuged $(6500 \mathrm{x} \mathrm{g} / 15 \mathrm{~min})$ and filter sterilized (Millipore $0.20 \mu \mathrm{m})$. An aliquot $(1 \mathrm{~mL}$ ) of sterilized supernatant was added into $1 \mathrm{~mL}$ of YM medium (tube $120 \times 13 \mathrm{~mm}$ ), and inoculated with $P$. expansum strain \#2 (10 5 spores). A control without supernatant $\left(10^{5}\right.$ spores of $P$. expansum strain \#2 in $1 \mathrm{~mL}$ sterile water plus $1 \mathrm{~mL}$ YM medium) was used for the comparison. The tubes were incubated at $25^{\circ} \mathrm{C} / 12 \mathrm{~h}$, and microscopic analysis of conidia germination percentage and fungal growth determination by measuring the hyphal length. One inhibition unit (UI) was defined as $50 \%$ conidia inhibition or $50 \%$ hyphal growth inhibition (Chen et al., 1999). The experiment in three repetitions was carried along four months. For each repetition, the hyphal lengths were measured for 40 randomly selected hyphae and the mean hypha length was used for the comparison. Conidia germination was based on four counts of 100 conidia per repetition (Chen et al., 1999). The data of three repetitions were analysed by Tukey test (ANOVA/MANOVA) comparing the mean values obtained from 120 data for hyphal length and 12 data for propagules percentage. 


\section{Toxigenicity of $\boldsymbol{P}$. expansum}

$P$. expansum strain $\# 2$ toxigenicity was determined by the high-performance liquid chromatography (HPLC, Shimadzu, Japan). Ten mg of working standard of patulin $(99.0 \%$ purity-ACROS, New Jersey, USES) was dissolved in $1 \mathrm{~mL}$ chloroform, subdivided in five flasks $(200 \mu \mathrm{L})$, dried under $\mathrm{N}_{2}$ gas and stored at $-20^{\circ} \mathrm{C}$. Patulin was suspended in ethanol and quantified at $275 \mathrm{~nm}$ (Cintra 20), according to the "Official Methods of Analysis"AOAC (2000), procedure n. 974.18.

$P$. expansum was grown in 10 Erlenmeyer flasks with $25 \mathrm{~mL}$ of malt extract ( $\mathrm{pH} 4.4$ ) (malt extract $0.6 \%$, dextrose $0.6 \%$, maltose $0.18 \%$, yeast extract $0.14 \%$ ) at $25^{\circ} \mathrm{C} / 15$ days and the filtrate was submitted to three partitions with $25 \mathrm{~mL}$ of ethyl acetate. Pooled organic phases $(750 \mathrm{~mL})$ were dried with $100 \mathrm{~g}$ anhydrous sodium sulfate (30 min) and evaporated at $40^{\circ} \mathrm{C}$ until aproximately 25 $\mathrm{mL}$. The solution was cleaned up using silica gel column $(500 \times 10 \mathrm{~mm}$, with $8.5 \mathrm{~g}$ of silica gel 60G, 70-230 mesh, MERCK). Briefly, the solution was introduced into the column and the elution was carried out with $100 \mathrm{~mL}$ benzene/ethyl acetate $(75: 25)$. The eluate was collected, evaporated at $40^{\circ} \mathrm{C}$ until aproximately $5 \mathrm{~mL}$, and dried under $\mathrm{N}_{2}$ gas (AOAC, 2000).

Residue was dissolved in $100 \mu \mathrm{L}$ of acetonitrile/water (1:9), and analysed by the reversed-phase HPLC (Shimadzu, Japan), equipped with a CTO-10A VP column oven, a LC10AD pump, and a SPD-10 UV detector. Separations were performed on a $250 \times 4.6 \mathrm{~mm}$ I.D. $\mathrm{C}_{18}$ column of $5 \mu \mathrm{m}$ diameter (Trennsaule). The mobile phase was acetonitrile/water (5:95), and the flow rate was $1.5 \mathrm{~mL} / \mathrm{min}$; the elution was monitored by UV absorption at $275 \mathrm{~nm}$ (Kawashima et al., 2002). Under these conditions, patulin has a retention time of $7.4 \mathrm{~min}$. Patulin was quantified by comparing the peak areas in the sample with those of an authentic reference standard (ACROS, New Jersey, USA) at 7 concentration levels: $0.020 ; 0.035 ; 0.050 ; 0.100$; $0.200 ; 0.250$; and $0.350 \mu \mathrm{g} / \mathrm{mL}\left(\mathrm{R}^{2}=0.999\right)$. The detection limit of the toxin was measured as three times the baseline standard deviation of blank $(0.020 \mu \mathrm{g} / \mathrm{mL})$, and the quantification limit was measured as five times the detection limit (Codex Alimentarius Commission, 1998; Valente Soares, 2001).

\section{Patulin degradation by $P$. ohmeri}

The assay of patulin degradation was carried out adding $223 \mu \mathrm{g}$ of patulin (previously produced by $P$. expansum, as described on item 2.4.) in four Erlenmeyer flasks with $25 \mathrm{~mL}$ of Yeast Medium (YM) $\mathrm{pH} 4.0$, and inoculated with P. ohmeri $(3.0 \mathrm{x}$ $10^{6}$ cells). Four more Erlenmeyer flasks ( $25 \mathrm{~mL}$ of $\mathrm{YM} \mathrm{pH}$ 4.0) were added with patulin alone (without yeast) as control, in order to check patulin stability during assay. After 2, 5, 10 and 15 days incubation at $25^{\circ} \mathrm{C}$ in a Biochemical Oxygen Demand (B.O.D., MERCK), remained patulin was quantified as described above (AOAC, 2000) and $\mathrm{pH}$ value was determined.

\section{Statistical analysis}

The mean values of hyphal length measurement and propagules percentage from the antifungal assay analysed for the antagonistic activity were compared by Tukey test using ANOVA/MANOVA program (STATISTICA version 5.0, 1995).

\section{RESULTS AND DISCUSSION}

In the previous studies, screening of 44 yeasts isolated from the different ecosystem source resulted 20 antagonists with any anti-Penicillium expansum strain \#2 activity (Levy et al., 2002; Levy, 2003; Coelho, 2005). Eight antagonist yeasts were isolated from the apple ( $P$. membranifaciens strains A1 to A7; Sporobolomyces roseus strain A8), three from the corn silage (Debaryomyces hansenii strains C1; C5; C7), 6 from anthill (P. ohmeri 158; Aureobasidium sp. 102; Candida homilentoma 69; D. hansenii $31 ; P$. anomala $142 ; P$. guilliermondii 42), 1 from papaya (C. guilliermondii $\mathrm{P} 3$ ) and 2 from grape fruits (Rhodotorula mucilaginosa strains G3 and G5). Fifteen antagonists showed inhibitory activity against $P$. expansum strain \#2 based mainly on nutrient and space competition. The assay in solid medium $\left(25^{\circ} \mathrm{C} / 120 \mathrm{hrs}\right)$ pointed the strongest nutrient competition antagonism by D. hansenii strain C1 (31 mm inhibition diameter), while $D$. hansenii strain $C 7(15 \mathrm{~mm})$ showed higher antibiosis and parasitism pattern (Levy et al., 2002; Coelho, 2005).

Taking into account the approach concerning the antagonism based on antibiosis, the extracellular activity was tested performing the assay with 
culture supernatant in YM agar, against $P$. expansum strain \#2 (10 ${ }^{5}$ spores). This assay reduced the number of active isolates into five $(D$. hansenii strain C7; P. membranifaciens strains A4 and A8; C. guilliermondii strain P3; and P. ohmeri strain 158), with the culture supernatant of $C$. guilliermondii $\mathrm{P} 3$ and $P$. ohmeri 158 showing higher antagonism, indicating probable production of effective extracellular compounds (data not shown, Coelho, 2005).

In this work, the antagonism of P. ohmeri 158 against $P$. expansum was evaluated in broth culture due to the sensibility of the method, with microscopic analysis that allowed the measurement of hyphal length and conidia germination percentage. Testing the incubationtime range from 24 to $120 \mathrm{~h}$ of $C$. guilliermondii P3 and P. ohmeri 158 in YM broth, both yeasts culture supernatants showed higher inhibitory activity at 48 and $72 \mathrm{~h}$ incubation time. $C$. guilliermondii P3 was more effective against conidia germination (inhibition rate of $58.15 \%$ ) while $P$. ohmeri showed better inhibition on micelial growth $(66.17 \%$, Figure 1$)$. The exogenous compound activity associated with antibiosis could probably be related with the killer phenomenon, once both strains were killer positive against S. cerevisiae NCYC 1006 (Coelho, 2005). Among the 20 yeasts showing anti-Penicillium activity, 9 were identified as killer positive, suggesting involvement of such factor as promising agent in the control of patulin producing $P$. expansum. Walker et al. (1995) reported susceptibility of yeast and filamentous fungi caused by killer positive strains of $S$. cerevisiae, $P$. anomala and Williopsis mrakii.

The killer phenotype is based on the secretion of a low molecular mass protein or glycoprotein toxin able to kill sensitive cells belonging to the same or related yeast genera, but without direct cell-cell contact (Bevan and Makower, 1963). A Pichia strain (CCA 510) showed the best killer activity against $92 \%$ of isolated fermentative yeasts of the process (Ceccato-Antonini et al., 2004). De La Pena et al. (1981) demonstrated that $S$. cerevisiae toxin was a protein which bond to a receptor on cell wall of sensitive yeasts, disrupting the electrochemical gradient across the cell membrane and hence the intracellular ionic balance. The zigocin secreted by Zygosaccharomyces bailii was a rapid process mostly related with the disruption of cytoplasmic membrane function in vivo (Weiler and Schmitt, 2003). Wicaltin, a chromosomal killer toxin in Williopsis californica, as the HK toxin of Hansenula mrakii were targeted to $\beta-1,3-$ D-glucan skeleton in the cell wall (Yamamoto et al., 1986; Theisen et al., 2000).

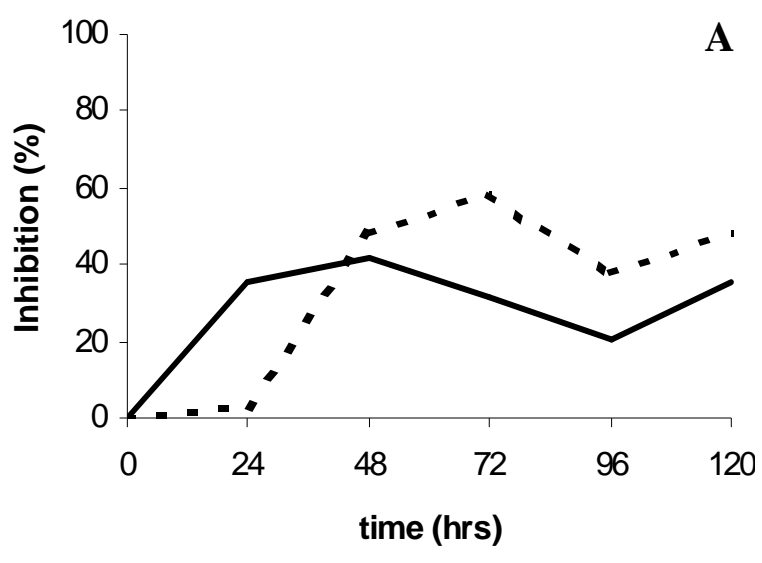

— Hyphal growth inhibition

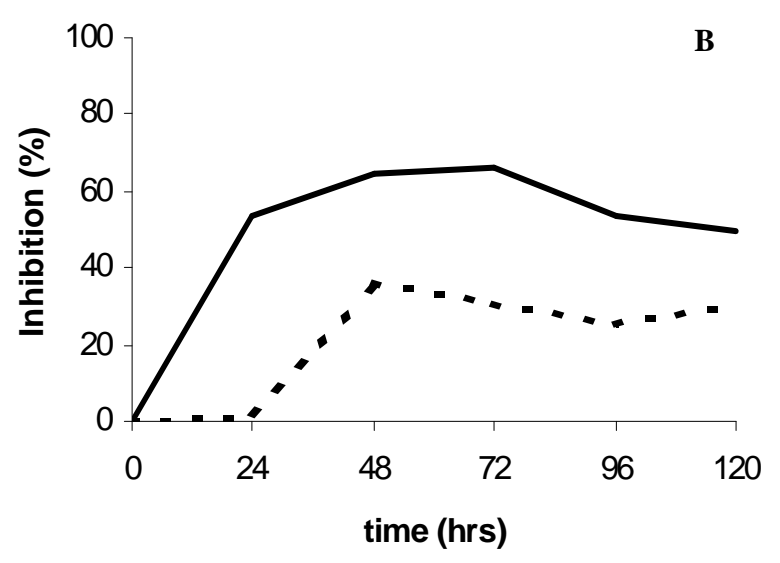

- _. Conidia germination inhibition

Figure 1 - Inhibitory activity of $C$. guilliermondii P3 (A) and P. ohmeri 158 (B) culture supernatant against germination and hyphal growth of $P$. expansum $\# 2$ (10 5 spores) after $12 \mathrm{hrs}$ at $25^{\circ} \mathrm{C}$ in static condition. 
Previous microscopic analysis data showed consistent attachment of $D$. hansenii $\mathrm{C} 7$ onto cell wall of $P$. expansum hyphae (Levy, 2003). Attachment of yeast cells on mycelium surface of the pathogen and subsequent changes in hyphae viability suggested the antagonistic activity based on hyperparasitism. Arras et al. (1998) also reported attachment of $P$. guilliermondii onto $P$. italicum mycelium. Wisniewski et al. (1991) reported the attachment of $P$. guilliermondii onto Botrytis cinerea mycelium. C. oleophila I-182 in Aspire $^{\circledR}$ by Ecogen, Langhorne, PA (Sugar and Spotts, 1999; El Ghaouth et al., 2000) and Cryptococcus albidus in Yield Plus ${ }^{\circledR}$ (Ancor Yeast, Cape Town, South Africa), both with antagonistic activiy based on hyperparasitism, which have already been commercialized in the United States (El Ghaouth et al., 2000; Droby et al., 2003).

Considering that such a biological control property would be enhanced if the bioactive yeasts also could degrade the produced mycotoxin, the preliminary study with $P$. membranifaciens and $S$. roseus decreased the initial patulin level from 588.4 to $290.0 \mu \mathrm{g}$ after incubation at $25^{\circ} \mathrm{C} / 15$ days (Levy et al., 2002). Taking this into account, and the best effectivness of $P$. ohmeri 158 against $P$. expansum hyphal growth in the present work, ability of $P$. ohmeri 158 in patulin degradation was performed. Added patulin was decreased over $83 \%$ of the original content, when incubated with $P$. ohmeri at $25^{\circ} \mathrm{C} / 48 \mathrm{~h}$ in the static condition and completely destroyed after 15 days with undetectable patulin level (Figure 2).

The patulin content in the controls remained between $140 \mu \mathrm{g} / 25 \mathrm{~mL}$ (or $5.6 \mu \mathrm{g} / \mathrm{mL}$ ) and 180 $\mu \mathrm{g} / 25 \quad \mathrm{~mL}$ (or $7.2 \mu \mathrm{g} / \mathrm{mL}$ ) along 15 days experiment and the different values observed suggested problems during the mycotoxin extraction procedure (Fig. 2). The detection limit by HPLC-UV detector for the pure standard was $6.7 \mathrm{ng} / \mathrm{mL}$. The limit of the quantification was determined as the smallest quantity of the toxin that allowed confirmation by the spectrum obtained. In this study the quantification limit was $0.03 \mu \mathrm{g} / \mathrm{mL}$.

The $\mathrm{pH}$ values were accomplished in order to determine patulin stability during the assay, as this mycotoxin was stable in solutions at $\mathrm{pH}$ ranging from $\mathrm{pH} 3.0$ to 5.5 (Engel and Teuber, 1984), i.e., compatible with $\mathrm{pH}$ values $(\mathrm{pH}$ 2.9-3.3) in natural apple fruits (Jay et al., 2005). The initial $\mathrm{pH}$ of 4.0 decreased to $\mathrm{pH} 3.3$ along 15 days of P. ohmeri cultivation in YM broth (Figure 2), suggesting that patulin decrease was an active process and a consequence of yeast metabolism, i.e., this mycotoxin was unstable at alkali solutions (Engel and Teuber, 1984). The patulin decrease using yeasts could be explained by two possible hypotheses. The first one suggested patulin degradation by an enzymic action during the fermentative condition associated with an inducible process. Sumbu et al. (1983) demonstrated that yeast cells preconditioned to grow in the presence of $50 \mu \mathrm{g} / \mathrm{mL}$ of patulin for 3 $\mathrm{h}$ and submitted to apple juice spiked with higher patulin concentrations, they became resistant to the doses of $>200 \mu \mathrm{g} / \mathrm{mL}$, indicating an inducible process. This phenomenon was confirmed when the toxin was added into juice simultaneously with cycloheximide, an antifungal agent which blocked the peptide bond formation, resulting in repression of protein synthesis without toxin decrease (Sumbu et al., 1983). Stinson et al. (1978) reported complete degradation of patulin during fermentation of apple juice to wine by $S$. cerevisiae. Moss and Long (2002) showed decreasing patulin level by $S$. cerevisiae fermentative process, reducing this toxin to (E)ascladiol, in contrast with lower biodegradation effectiveness in shaken flask culture.

The second hypothesis suggested that the toxin decrease could be associated with the adsorption ability of yeast cell wall components, such as glucan/mannan. For example, Yiannikouris et al. (2004) showed that $S$. cerevisiae strains with high cell wall glucan content exhibited higher affinity rates for zearalenone, when their total cell wall fraction (TCW) and its alkali-insoluble glucan fraction (AIG) were submitted to the toxin. Furthermore, the best adsorption efficacy of AIG was evidenced by the chitin content decreasing compared to the TCW fraction, thus increasing glucan flexibility and toxin accessibility to the glucan network (Yiannikouris et al., 2004).

Although any toxicological or epidemiological data in humans was not reported, the presence of patulin could be indicative of the quality of fruit used in the processed apple products (Moss, 1996; Leggott et al., 2001). Recently, "The Guidance Document of FDA Components and Industry on Apple Juice and Apple Juice Products" 
recommended that level of patulin in fruit juice and fruit products should be lower than $50 \mu \mathrm{g} / \mathrm{L}$ (Richard et al., 2003), and the European Commission established $25 \mu \mathrm{g} / \mathrm{kg}$ as maximum level for patulin in solid apple products, including apple compote and puree and $10 \mu \mathrm{g} / \mathrm{kg}$ in apple products intended for the infants and young children (European Commission, 2003; Boonzaaijer et al., 2005). The World Health Organization (WHO) altered the limit of patulin ingestion from 7.0 to $0.4 \mu \mathrm{g} / \mathrm{kg}$ bw/day (Bolger, 2002; Baert et al., 2004).

A
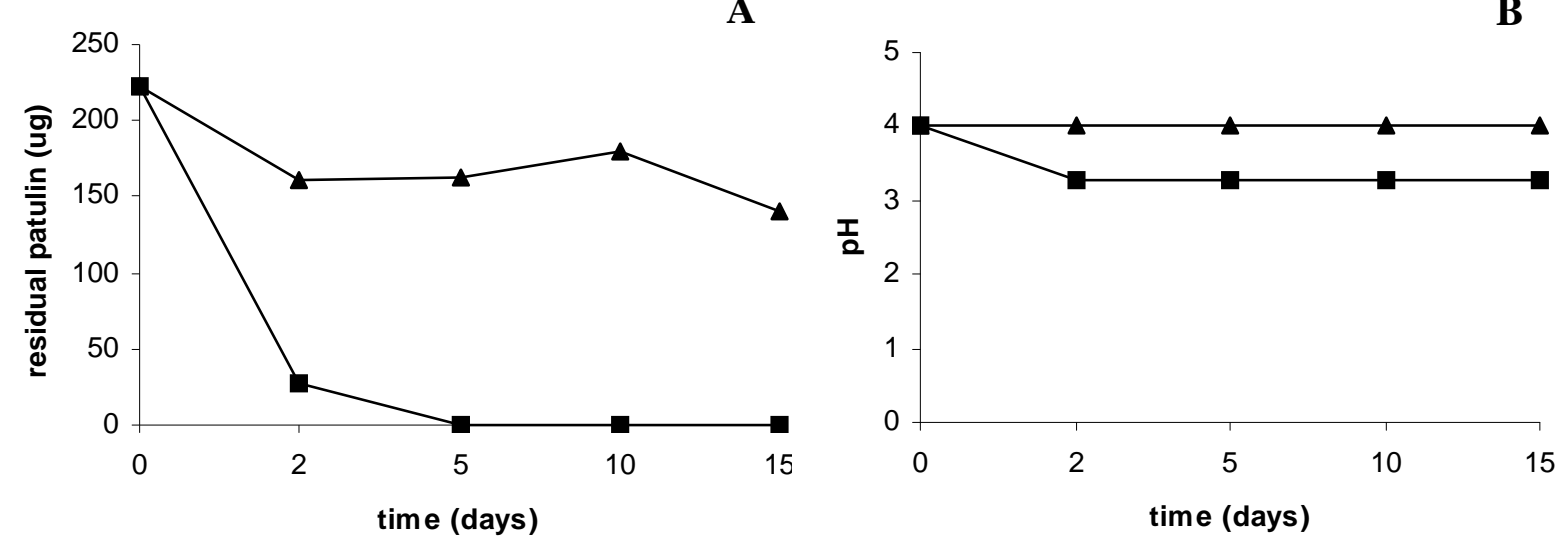

Figure 2 - Decrease of patulin (A) and pH determination (B) along 15 days by P. ohmeri 158 cultivation in Yeast Medium. $\boldsymbol{\Delta}$, Yeast Medium added with patulin alone (control); $\mathbf{\square}$, Yeast Medium added with patulin and P. ohmeri 158.

Burda (1992) found patulin levels between 51 and $1130 \mu \mathrm{g} / \mathrm{L}$ and Gokmen and Acar (1998) reported the presence of patulin in 215 samples ranging from 7 to $376 \mu \mathrm{g} / \mathrm{L}$. Concentrations between 15 and $285.3 \mu \mathrm{g} / \mathrm{L}$ of patulin in apple juice produced in Iran were found by Cheraghali et al. (2005). However, this toxin could reach higher levels when juices were made from the visibly rotten apples, ranging from 500 to $2500 \mu \mathrm{g} / \mathrm{L}$ (Steiner et al., 1999), or when fruits artificially contaminated with $P$. expansum NRRL 1172 or toxigenic $P$. variabile were stored at 0 and $4^{\circ} \mathrm{C}$ during 90 days, with patulin levels between 1066 and $6400 \mu \mathrm{g} / \mathrm{L}$ (Ross-Urbano et al., 1998).

It should be noted that the patulin level used in the present study $(223 \mu \mathrm{g} / 25 \mathrm{~mL}$; or $8.92 \mu \mathrm{g} / \mathrm{mL})$ and the patulin content in the controls along 15 days experiment $(140-180 \mu \mathrm{g} / \mathrm{mL}$; or $5.6-7.2 \mu \mathrm{g} / \mathrm{mL}$ ) were higher than that recommended by the European Commission (2003) and those normally found in the apple and apple juices, and consequently not safe for human consumption, indicating that it would be possible to reduce significantly high doses of patulin to an acceptable or undetectable level using yeasts as biodegradation agents, once P. ohmeri was commonly used in fermentative process in the food industry (Kurtzman and Fell, 1998). The effective antagonism of $P$. ohmeri versus $P$. expansum hyphal growth showed in this work suggested that the inhibition of fungal development was a promising alternative for the biologial control, and consequently should guarantee a low or undetectable patulin levels. However, further studies would be necessary to determine the likely mode of action of P. ohmeri against patulin decrease.

To concludes, the frequent occurrence of $P$. expansum in apple fruits associated with patulin hazard in quality control at the harvesting and storage stages, suggested that the use of nondeleterious antagonist yeasts screened from the natural ecosystem, with additional biodegradation /adsorption properties should be an effective and profitable choice of biological control to avoid the fruit spoilage and mycotoxin production by the post-harvest fungi, to the increased trading of fruits. 


\section{ACKNOWLEDGEMENTS}

The authors would like to thank National Council of Scientific and Technological Development (CNPq, Brazil), CAPES-Brazil and Araucaria Foundation for financial support.

\section{RESUMO}

Considerando o antagonismo e degradação de patulina detectados em Pichia membranifaciens e Sporobolomyces roseus no estudo preliminar, este trabalho avaliou o efeito antagônico de Pichia ohmeri 158 no desenvolvimento de Penicillium expansum e a degradação de patulina "in vitro". O sobrenadante do cultivo de P. ohmeri 158 inibiu $66,17 \%$ do desenvolvimento micelial, indicando antibiose relacionada ao fator killer. A concentração inicial de patulina $(223 \mu \mathrm{g})$ na presença de células íntegras de $P$. ohmeri foi reduzida em mais de $83 \%$ após dois dias de incubação a $25^{\circ} \mathrm{C}$ e superior a $99 \%$ após 5 dias, com níveis indetectáveis no $15^{\circ}$ dia. O decréscimo do $\mathrm{pH}$ 4,0 inicial para $\mathrm{pH}$ 3,3 sugeriu que a eliminação de patulina é um processo ativo e uma consequiência do metabolismo da levedura. Os resultados obtidos concluem que $P$. ohmeri 158 é uma alternativa promissora na inibição do desenvolvimento de $P$. expansum e na degradação de patulina.

\section{REFERENCES}

Arras, G.; De Cicco, V.; Arru, S. and Lima, G. (1998), Biocontrol by yeasts of blue mould of citrus fruits and the mode of action of an isolate of Pichia guilliermondii. Journal of Horticultural Science and Biotechnology, 73, 3, 413-418.

Association of Official Analytical Chemists-AOAC. (2000), Official method 974.18. Patulin in apple juice-Thin-layer chromatographic method. Official methods of analysis. Washington. Journal of AOAC, DC, 57, 61 .

Baert, K.; Chitundu, K.; De Meulenaer, B. and Devliedhere, F. (2004), Incidence of patulin in organic and conventional apple juice marketed in Belgium. Paper presented at XI International IUPAC Symposium on Mycotoxins and Phycotoxins, Bethesda, Maryland, USA.
Barnett, J. A.; Payne, R. W. and Yarrow, D. (1990), Yeasts: characteristics and identification. 2. ed. [S.1.]: Cambridge University Press, $1002 \mathrm{p}$.

Bevan, E. A. and Makower, M. (1963), The physiological basis of the killer character in yeast. Paper presented at XI International Congress of Genetic, 202-203.

Bolger, M. (2002), Integration of risk assessment and management. Paper presented at Joint FAO/WHO seminar on the safety/risk analysis of contaminants: genotoxic carcinogens, Rotterdam, The Netherlands.

Boonzaaijer, G.; Bodeldijk, I. and Van Osenbruggen, W. A. (2005), Analysis of patulin in dutch food, an evaluation of a SPE based method. Food Control, 16, 587-591.

Burda, K. A. (1992), Research Note: Incidence of patulin in apple, pear, and mixed fruit-products marketed in New South Wales. Journal of Food Protection, 55, 10, 796-798.

Castoria, R.; De Curtis, F.; Lima, G.; Caputo, L.; Pacifico, S. and De Cicco, V. (2001), Aureobasidium pullulans (LS-30) an antagonist of post-harvest pathogens of fruits: study on its modes of action. Post-harvest Biology and Technology, 22, 7-17.

Ceccato-Antonini, S. R.; Tosta, C. D. and Silva, A. C. (2004), Determination of yeast killer activity in fermenting sugarcane juice using selected ethanolmaking strains. Brazilian Archives of Biology and Technology, 47, 1, 13-23.

Chen, Z.; Brown, R. L.; Lax, A. R. and Cleveland, T. E. (1999), Inhibition of plant-pathogenic fungi by a corn trypsin inhibitor overexpressed in Escherichia coli. Applied and Environmental Microbiology, 65, 3, 1320-1324.

Cheraghali, A. M.; Mohammadi, H. R.; Amirahmadi, M.; Yazdanpanah, H.; Abouhossain, G.; Zamanian, F.; Khansari, M. G. and Afshar, M. (2005), Incidence of patulin contamination in apple juice produced in Iran. Food Control, 16, 165-167.

Codex Alimentarius Commission. (1998), Criteria for evaluating acceptable methods of analysis for codex purposes, Codex Committee on Methods of Analysis and Sampling. Document CX/MAS 98/5, 1998.

Coelho, A. R. (2005), Controle de Penicillium expansum/biodegradação de patulina: perfil cromatográfico de composto bioativo de leveduras killer visando aplicação pós-colheita (2005), Tese (Doutorado em Ciência de Alimentos), Universidade Estadual de Londrina, Londrina, Brasil.

De La Peña, P.; Barros, F.; Gascón, S.; Lazo, P. S. and Ramos, S. (1981), Effect of yeast killer toxin on sensitive cells of Saccharomyces cerevisiae. The Journal of Biological Chemistry, 256, 20, 1042010425. 
Droby, S.; Wisniewski, M.; El Ghaouth, A. and Wilson, C. (2003), Influence of food additives on the control of post-harvest rots of apple and peach and efficacy of the yeast-based biocontrol product Aspire. Postharvest Biology and Technology, 27, 127-135.

El Ghaouth, A.; Smilanick, J. L.; Wisniewski, M. and Wilson, C. L. (2000), Improved control of apple and citrus fruit decay with a combination of Candida saitoana and 2-deoxy-D-glucose. Plant Disease, 84, 249-253.

Engel, G. and Teuber, M. (1984), Patulin and other small lactones. In-Mycotoxins. $1^{\circ}$ ed. Netherland, 290-299.

European Commission (2003), Ec No 1425/2003.

Food and Drug Administration-FDA (2002), available at: <http://www.cfsan.fda.gov/ dms/opa-micr.html>. Accessed in: 14 aug., 2002.

Gokmen, V. and Acar, J. (1998), Incidence of patulin in apple juice concentrates products in Turkey. Journal of Chromatography, 815, 99-192.

Hopkins, J. (1993), The toxicological hazards of patulin. Food Chemistry Toxicology, 31, 455-459.

Hussein, H. S. and Brasel, J. M. (2001), Toxicity, metabolism, and impact of mycotoxins on humans and animals. Toxicology, 167, 2, 101-134.

Janisiewicz, W. J.; Tworkoski, T. J. and Sharer, C. (2000), Characterizing the mechanism of biological control of post-harvest diseases on fruits with a simple method to study competition for nutrients. Phytopathology, 90, 11, 1196-1200.

Jay, J. M.; Loessner, M. J. and Golden, D. A. (2005), Modern Food Microbiology. 750 p.

Kawashima, L. M.; Valente Soares, L. M. and Massaguer, P. R. (2002), The development of an analytical method for two mycotoxins, patulin and verruculogen, and survey of their presence in commercial tomato pulp. Brazilian Journal of Microbiology, 33, 269-273.

Kreeger Van Rij, N. J. W. (1984), The yeasts: a taxonomic study. [S.1.]: Elsevier Science Publication.

Kurtzman, C. P. and Fell, J. W. (1998), The yeasts, a taxonomic study. 4 ed., 1055 p.

Leggott, N. L.; Shephard, G. S.; Stockenstrom, S.; Staal, E. and Schalkwyk, D. J. (2001), The reduction of patulin in apple juice by three different types of activated carbon. Food Additives and Contaminants, 18, 9, 825-829.

Levy, R. M. Aplicação de leveduras no controle de Penicillium expansum. (2003), Tese (Doutorado em Ciência de Alimentos), Universidade Estadual de Londrina, Londrina, Brasil.

Levy, R. M.; Hayashi, L.; Carreiro, S. C.; Pagnocca, F. C. and Hirooka, E. Y. (2002), Inhibition of mycotoxigenic Penicillium sp. and patulin biodegradation by yeast strains. Revista Brasileira de Armazenamento, 27, 1, 41-47.

Moss, M. O. (1996), Mycotoxins. Mycological Research, 100, 5, 513-523.
Moss, M. O. and Long, M. T. (2002), Fate of patulin in the presence of the yeast Saccharomyces cerevisiae. Food Additives and Contaminants, 19, 4, 387-399.

Ono, E. Y. S.; Biazon, L.; Silva, M.; Vizoni, E.; Sugiura, Y.; Ueno, Y. and Hirooka, E. Y. (2006), Fumonisins in corn: correlation with Fusarium sp. count, damaged kernels, protein and lipid content. Brazilian Archives of Biology and Technology, 49, 1, 63-71.

Pitt, J. I.; Basílico, J. C.; Abarca, M. L. and López, C. (2000), Mycotoxins and toxigenic fungi. Medical Mycology, 38, 41-46.

Richard, J.; Payse, G.; Desjardins, A. E.; Maragas, C. and Norred, W. (2003), Mycotoxins, risk in plant, animal and human systems. Council of Food Protective, 71.

Ross-Urbano, G.; Taniwaki, M. H.; Sabino, M.; Vizoni, T. and Hirooka, E. Y. (1998), Produção de patulina em maçã (Malus domestica Borkhausen), cultivares Gala e Fuji inoculadas com Penicillium spp. Ciência e Tecnologia de Alimentos, 18, 1, 63-67.

Sharma, R. P. (1993), Immunotoxicity of mycotoxins. Journal of Dairy Science, 76, 892-897.

Statistica for Windows (1995), Inc. Tulska OK, USA.

Steiner, I.; Werner, D. and Washutti, J. (1999), Patulin in fruit juices. Part 1. Analysis and control in Austrian apple and pear juices. Ernaehrung, 23, 202208.

Stinson, E. E.; Osman, S. F.; Huhtanen, C. N. and Bills, D. D. (1978), Disappearance of patulin during alcoholic fermentation of apple juice. Applied and Environmental Microbiology, 36, 4, 620-622.

Sugar, D. and Spotts, R. A. (1999), Control of postharvest decay in pear by four laboratory-grown yeasts and two registered biocontrol products. Plant disease, 83, 2, 155-158.

Sumbu, Z.; Thonart, P. and Bechet, J. (1983), Action of patulin on a yeast. Applied and Environmental Microbiology, 45, 1, 110-115.

Theisen, S.; Molkenau, E. and Schmitt, M. J. (2000), Wicaltin, a new protein toxin secreted by the yeast Williopsis californica and its broad-spectrum antimycotic potential. Journal of Microbiology and Biotechnology, 10, 547-550.

Usall, J.; Teixido, N.; Torres, R.; De Eribe, X. O. and Vinas, I. (2001), Pilot tests of Candida sake (CPA-1) applications to control post-harvest blue mold on apple fruit. Post-harvest Biology and Technology, 21, 2, 147-156.

Valente Soares, L. M. (2001), Como obter resultados confiáveis em cromatografia. Revista Instituto Adolfo Lutz, 60, 1, 79-84.

Walker, G.; McLeod, A. and Hodgson, V. (1995), Interactions between killer yeast and pathogenic fungi. FEMS Microbiology, 127, 213-222. 
Weiler, F. and Schmitt, M. J. (2003), Zygocin, a secreted antifungal toxin of the yeast Zygosaccharomyces bailii, and its effect on sensitive fungal cells. FEMS Yeast Research, 3, 69-76.

Wisniewski, M. E.; Biles, C.; Droby, S.; McLaughlin, R.; Wilson, C. L. and Chalutz, E. (1991), Mode of action of the post-harvest biocontrol yeast Pichia guilliermondii. I. Characterization of attachment to Botrytis cinerea. Physiology Molecular Plant Pathology, 39, 245-258.

World Health Organization-International Agency for Research on Cancer-WHO-IARC (1996), Evaluation of certain food additives and contaminants. WHO Technical Report Series, 859.
Wouters, M. F. A. and Speijers, G. J. A. (1996), Patulin. In-Toxicological evaluation of certain food additives and contaminants. World Health Organization, Geneva, 337-402.

Yamamoto, T.; Hiratani, T.; Hirata, H.; Imai, M. and Yamaguchi, H. (1986), Killer toxin from Hansenula mrakii selectively inhibits cell wall synthesis in a sensitive yeast. FEMS Microbiology Letters, 197, 1-2, 50-54.

Yiannikouris, A.; Poughon, L.; François, J.; Cameleyre, X.; Dussap, G. A.; Bertin, G. and Jouany, J. P. (2004), Study of adsorption capacity of yeast cell wall components towards zearalenone. Paper presented at XI International IUPAC Symposium on Mycotoxins and Phycotoxins, Bethesda, Maryland, USA. 
PÁGINA

EM

BRANCO 